\title{
Hubungan Inisiasi Menyusu Dini dan ASI Eksklusif dengan Stunting pada Baduta Usia 7-24 Bulan
}

\author{
Nur Annisa ${ }^{1^{*}}$, Sumiaty ${ }^{2}$, Henrietta Imelda Tondong ${ }^{1}$ \\ ${ }^{1}$ Prodi D-IV Kebidanan, Jurusan Kebidanan, Poltekkes Kemenkes Palu, \\ ${ }^{2}$ Prodi D-III Kebidanan Palu, Jurusan Kebidanan, Poltekkes Kemenkes Palu, \\ `Email korespondensi: nurannisha00@gmail.com
}

Article Info

Article history:

Submitted: 2019-07-10

Accepted: 2019-08-03

Published: 2019-08-31

Keywords:

Early breastfeeding initiation;

exclusive breastfeeding; stunting;

\section{ABSTRACT}

Stunting can be caused by a variety of factors, such as the implementation of initiation of early breastfeeding which is not appropriate and the provision of breast milk is not exclusive. The purpose of this study was to know the relationship between early breastfeeding initiation and exclusive breastfeeding with stunting in twoyear-old infants aged 7-24 months in the work area of Pantoloan Health Center. This type of research was an analytical survey with design cross-sectional. The sample in this study were two-year-old infants aged 7-24 months totaling 57 samples with sampling techniques namely proportional random sampling and data analysis using Chi-Square. The results showed that respondents who experienced stunting were $36.8 \%$ and not stunting $63.2 \%$. Respondents who had early breastfeeding initiationn din not tend to experience stunting (79.2\%), while respondents who received exclusive breastfeeding tended not to experience stunting $(81.0 \%)$. The results of the statistical test showed a significant relationship between early breastfeeding initiation and exclusive breastfeeding with stunting with the same $p$-value of 0.033 $(\alpha<0.05)$. The conclusion is that there was a relationship between early breastfeeding initiation and exclusive breastfeeding with stunting. Suggestions for researchers and for health workers to maximize promote and implement early breastfeeding initiations and exclusive breastfeeding for mothers to prevent and minimize the incidence of stunting in children in the future.

\section{ABSTRAK}

Kata Kunci:

Inisiasi Menyusui Dini; ASI Eksklusif; Stunting;
Stunting dapat disebabkan oleh berbagai faktor, seperti pelaksanaan Inisiasi Menyusu Dini (IMD) yang kurang tepat dan pemberian Air Susu Ibu (ASI) secara tidak eksklusif. Tujuan penelitian ini diketahuinya hubungan IMD dan pemberian ASI eksklusif dengan stunting pada BADUTA usia 7-24 bulan di wilayah kerja Puskesmas Pantoloan. Jenis penelitian ini adalah survei analitik dengan rancangan cross sectional. Sampel dalam penelitian ini adalah BADUTA usia 7-24 bulan berjumlah 57 sampel dengan teknik pengambilan sampel yaitu proportional random sampling dan analisis data menggunakan uji Chi Square. Hasil penelitian menunjukkan bahwa responden yang mengalami stunting $36,8 \%$ dan tidak stunting $63,2 \%$. Responden yang inisiasi menyusu dini cenderung untuk tidak mengalami stunting $(79,2 \%)$, sedangkan responden yang mendapatkan ASI eksklusif cenderung untuk tidak mengalami stunting $(81,0 \%)$. Hasil uji statistik menunjukkan hubungan bermakna IMD dan pemberian ASI eksklusif dengan stunting dengan $\mathrm{p}$ value yang sama yakni $0,033(\alpha<0,05)$. Kesimpulan bahwa terdapat hubungan IMD dan pemberian ASI eksklusif dengan stunting. Saran peneliti bagi petugas kesehatan agar memaksimalkan dalam mempromosikan dan melaksanakan IMD dan ASI eksklusif kepada masyarakat, terutama ibu-ibu untuk mencegah dan meminimalkan kejadian stunting pada anak-anak di masa datang. 


\section{PENDAHULUAN}

Peningkatan gizi masyarakat menjadi fokus pembangunan kesehatan berkelanjutan atau Sustainable Development Goals (SDGs) dengan tujuan mengakhiri segala bentuk malnutrisi pada tahun 2030, termasuk mencapai target internasional 2025 untuk penurunan stunting dan wasting pada balita dan mengatasi kebutuhan gizi remaja perempuan, wanita hamil dan menyusui serta lansia. ${ }^{1}$ Stunting adalah kondisi gagal tumbuh pada balita yang ditandai dengan tinggi badan tidak sesuai dengan usia akibat dari kekurangan gizi kronis terutama dalam 1000 Hari Pertama Kehidupan (HPK), yaitu sejak di kandungan ibu sampai usia anak 2 tahun. Stunting dalam jangka panjang, dapat menyebabkan menurunnya kapasitas intelektual yang akan berpengaruh pada produktivitas saat dewasa serta meningkatkan risiko penyakit tidak menular. ${ }^{2}$

Data World Health Organization (WHO) tahun 2017, stunting secara global mempengaruhi sekitar 22,2\% atau 150,8 juta anak dibawah usia 5 tahun. Oleh karena itu, stunting menjadi target pertama dari 6 target WHO tahun 2025 untuk pengurangan $40 \%$ jumlah anak dibawah usia 5 tahun yang mengalami stunting. ${ }^{3}$ Data Riskesdas 2018, prevalensi stunting pada balita secara nasional tahun 2018 adalah $30,8 \%$ yang menurut standar WHO prevalensi stunting Indonesia dianggap berat karena berada pada kisaran 30-39\%. ${ }^{4}$ Prevalensi pendek tahun 2018 sebesar $30,8 \%$ terdiri dari $11,5 \%$ sangat pendek dan 19,3\% pendek. Prevalensi stunting pada BADUTA tahun 2018 sebesar $29,9 \%$ yang terdiri dari $12,8 \%$ sangat pendek dan $17,1 \%$ pendek, namun masih belum mencapai target Rencana Pembangunan Jangka Menengah Nasional (RPJMN) 2015-2019 yaitu penurunan stunting BADUTA hingga 28\%. ${ }^{5}$ Data status gizi balita Provinsi Sulawesi Tengah tahun 2017 menunjukkan prevalensi stunting mencapai $36,1 \%$ dengan presentase Kota Palu $36,8 \% .^{6}$

Masalah tidak tercukupnya gizi yang mengakibatkan gagal tumbuh (stunting) pada anak dapat disebabkan oleh berbagai faktor, seperti pelaksanaan inisiasi menyusu dini (IMD) yang kurang tepat dan pemberian Air Susu Ibu (ASI) secara tidak eksklusif. Inisiasi Menyusu Dini (IMD) yang kurang tepat atau tidak dilakukannya IMD berakibat pada tidak terpenuhinya nutrisi yang penting bagi bayi diawal kehidupannya. Penelitian yang dilakukan di Kenya terhadap 418 anak usia 024 bulan menemukan bahwa anak yang tidak IMD berisiko 2 kali untuk mengalami stunting dibandingkan yang mendapat IMD. ${ }^{7}$ Hasil penelitian lainnya menunjukkan bahwa IMD merupakan faktor risiko terhadap kejadian stunting karena BADUTA yang tidak IMD lebih berisiko 3 kali dibandingkan yang IMD. ${ }^{8}$

Selain itu, keberhasilan IMD menentukan kesuksesan pemberian ASI eksklusif (0-6 bulan). Komponen nutrisi yang terkandung pada ASI diperlukan oleh bayi, terutama hingga bayi berusia 2 tahun. Hal itu dikarenakan pada periode ini pertumbuhan dan perkembangan berlangsung pesat, terutama pertumbuhan fisik, fungsi saraf dan otak. ${ }^{9}$ Penelitian yang dilakukan di pedesaan Rwanda membuktikan bahwa pemberian ASI eksklusif meningkatkan pertumbuhan linier pada anak-anak yang kekurangan dan mengurangi risiko stunting..$^{10}$ Penelitian lainnya menunjukkan bahwa terdapat hubungan pemberian ASI eksklusif dengan kejadian stunting. ${ }^{11}$

Bayi dibawah dua tahun (BADUTA) berisiko mengalami stunting jika pada masa ini asupan zat gizi tidak mencukupi. Pada rentan usia BADUTA 7-24 bulan yang telah melewati masa ASI eksklusif, namun menunjukkan tanda-tanda stunting, peluang untuk memperbaiki panjang badan anak masih dapat dilakukan dengan dukungan orang tua untuk memberikan asupan gizi yang terbaik pada anak. 
Menurut laporan Dinas Kesehatan Kota Palu tahun 2018, wilayah kerja Puskesmas Pantoloan memiliki prevalensi stunting tertinggi di Kota Palu dengan jumlah temuan kasus stunting yaitu 54 anak usia 7-24 bulan yang terdiri dari pendek 48 anak dan sangat pendek 6 anak. ${ }^{12}$ Oleh karena itu, diperlukan penelitian untuk mengetahui riwayat IMD dan ASI eksklusif dengan kejadian stunting di wilayah tersebut. Tujuan penelitian ini adalah diketahuinya hubungan Inisiasi Menyusu Dini (IMD) dan pemberian Air Susu Ibu (ASI) eksklusif dengan stunting pada BADUTA usia 7-24 bulan di wilayah kerja Puskesmas Pantoloan.

\section{METODE PENELITIAN}

Penelitian ini merupakan penelitian kuantitatif dengan metode survei analitik dan rancangan yang digunakan adalah cross sectional. Penelitian ini dilaksanakan pada 09-18 Maret 2019 di posyandu dan rumah responden (door to door) yang ada di wilayah kerja Puskesmas Pantoloan. Populasi dalam penelitian ini adalah BADUTA usia 7-24 bulan yang berjumlah 301 anak. Sampel berjumlah 57 BADUTA dan pengambilan sampel menggunakan proporsi per posyandu dengan teknik proportional random sampling dengan mengundi nomor urut sampel. Teknik pengumpulan data yaitu peneliti melakukan wawancara dengan menggunakan format pengumpulan data atau check list yang berisi identitas keluarga, identitas BADUTA, inisiasi menyusu dini dan ASI eksklusif. Setelah itu, melakukan pengukuran panjang badan pada BADUTA dengan menggunakan alat infantometer dan hasilnya dibandingkan dengan indikator pengukuran PB/U yang mengacu pada standar KEPMENKES 2010. Analisis data menggunakan uji statistik Chi-Square (uji nonparametrik) untuk tabel $2 \times 2$.

\section{HASIL PENELITIAN}

Setelah data penelitian dianalisis maka diperoleh hasil sebagai berikut:

\section{Analisis Univariat}

Tabel 1. Distribusi frekuensi karakteristik berdasarkan umur, jenis kelamin dan penolong persalinan di wilayah kerja Puskesmas Pantoloan

$\begin{array}{lll}\text { Karakteristik } & \text { Frekuensi } & \text { Persentase (\%) }\end{array}$

\begin{tabular}{lrr}
\hline Umur & & \\
7-9 bulan & 7 & 12,3 \\
10-14 bulan & 19 & 33,3 \\
$15-19$ bulan & 18 & 31,6 \\
20-24 bulan & 13 & 22,8 \\
Jenis Kelamin & & \\
$\quad$ Perempuan & 31 & 54,4 \\
Laki-laki & 26 & 45,6 \\
Penolong Persalinan & & \\
Dokter & 9 & 15,8 \\
Bidan & 46 & 80,7 \\
Dukun & 2 & 3,5 \\
\hline
\end{tabular}

Sumber: Data primer, 2019

Berdasarkan Tabel 1 bahwa kelompok umur responden terbanyak pada umur 10-14 bulan sebanyak 33,3\%, kategori jenis kelamin yang dominan yaitu perempuan sebanyak $54,4 \%$ dan sebagian besar responden ditolong oleh Bidan dengan persentase $80,7 \%$. 
Tabel 2. Distribusi frekuensi status gizi stunting, Inisiasi Menyusu Dini (IMD) dan pemberian ASI Eksklusif di wilayah kerja Puskesmas Pantoloan

\begin{tabular}{lll}
\hline \multicolumn{1}{c}{ Variabel } & F & $\%$ \\
\hline Status Gizi Stunting & & \\
$\quad$ Stunting/Tidak Normal & 21 & 36,8 \\
$\quad$ Tidak Stunting/Normal & 36 & 63,2 \\
Inisiasi Menyusu Dini (IMD) & & \\
$\quad$ Tidak IMD & 33 & 57,9 \\
$\quad$ IMD & 24 & 42,1 \\
Pemberian ASI Eksklusif & & \\
$\quad$ Tidak ASI Eksklusif & 36 & 63,2 \\
$\quad$ ASI Eksklusif & 21 & 36,8 \\
\hline$\quad$ Total & 57 & 100 \\
\hline
\end{tabular}

Sumber: Data primer, 2019

Berdasarkan Tabel 2 dapat diketahui bahwa dari 57 responden, mayoritas dalam kategori status gizi normal (tidak stunting) sebanyak 63,2\%, namun sebagian besar responden tidak Inisiasi Menyusu Dini (IMD) sebanyak 57,9\% dan tidak mendapatkan ASI eksklusif sebanyak 63,2\%.

\section{Analisis Bivariat}

Tabel 3: Distribusi Inisiasi Menyusu Dini (IMD) dengan Stunting di wilayah kerja Puskesmas Pantoloan

\begin{tabular}{cccccc}
\hline \multirow{2}{*}{$\begin{array}{c}\text { Inisiasi Menyusu Dini } \\
\text { (IMD) }\end{array}$} & \multicolumn{4}{c}{ Status Gizi Stunting } & \multirow{2}{*}{ Nilai $\mathrm{p}$} \\
\cline { 2 - 5 } & $\mathrm{f}(\mathrm{n}=21)$ & $\%(36,8)$ & $\mathrm{f}(\mathrm{n}=36)$ & $\%(63,2)$ & \\
\hline Tidak IMD & 16 & 48,5 & 17 & 51,5 & \multirow{2}{*}{0,033} \\
IMD & 5 & 20,8 & 19 & 79,2 & \\
ASI Eksklusif: & & & & & \\
Tidak ASI Eksklusif & 17 & 47,2 & 19 & 52,8 & \multirow{2}{*}{0,033} \\
ASI Eksklusif & 4 & 19,0 & 17 & 81,0 & \\
\hline
\end{tabular}

Sumber: Data primer, 2019

Berdasarkan Tabel 3 menunjukkan bahwa responden yang memiliki riwayat inisiasi menyusu dini cenderung untuk tidak mengalami stunting di usia BADUTA $(79,2 \%)$ Hasil analisis uji chi-square diperoleh nilai $p$-value $0,033(\alpha<0,05)$ yang berarti terdapat hubungan yang bermakna inisiasi menyusu dini (IMD) dengan stunting.

Berdasarkan tabel 3 menunjukkan bahwa responden yang mendapatkan ASI selama 6 bulan tanpa makanan/minuman tambahan cenderung untuk tidak mengalami stunting (81,0\%). Hasil uji chi-square menunjukkan bahwa $p$-value 0,033 $(\alpha<0,05)$ yang berarti terdapat hubungan yang bermakna pemberian ASI eksklusif dengan stunting.

\section{PEMBAHASAN}

\section{Hubungan Inisiasi Menyusu Dini (IMD) dengan Stunting}

Hasil penelitian menunjukkan ada hubungan Inisiasi Menyusu Dini (IMD) dengan Stunting di wilayah kerja Puskesmas Pantoloan. Hasil penelitian sejalan 
dengan penelitian Sumiaty (2017) yang mencantumkan hasil analisis statistik bahwa terdapat hubungan variabel IMD dengan stunting. ${ }^{8}$

Hasil pengumpulan data yang dilakukan di lapangan diperoleh bahwa dari 21 BADUTA yang stunting, sebagian besar BADUTA tidak inisiasi menyusu dini yaitu $48,5 \%$ dan hanya $20,8 \%$ yang inisiasi menyusu dini. Hal itu dikarenakan sebagian besar $(57,1 \%)$ bayi diletakkan di dada ibu dilakukan selama kurang dari 30 menit dan/atau bayi tidak berhasil mendapatkan puting susu ibu selama pelaksanaan IMD sehingga pelaksanaan IMD menjadi tidak efektif. Ungkapan itu tidak sesuai dengan anjuran Kementerian Kesehatan (2010) bahwa pelaksanaan IMD dilakukan 30-60 menit dikarenakan sebagian besar bayi akan berhasil mendapatkan puting susu ibu dalam waktu 30-60 menit. ${ }^{9}$

Keberhasilan dalam mendapatkan puting susu memungkinkan bayi untuk menperoleh kolostrum. Zat gizi pada kolostrum dibutuhkan bayi pada awal-awal kehidupannya, termasuk untuk pertumbuhan tingginya. Hal itu karena kolostrum memiliki kandungan protein imunoglobulin A yang dapat memberikan perlindungan bagi bayi hingga usia 6 bulan. Selain itu, terdapat mineral yang dibutuhkan oleh bayi baru lahir, seperti kalsium, kalium dan natrium yang berperan dalam pembentukan tulang. ${ }^{9}$

Zat-zat gizi pada kolostrum juga membantu sistem pencernaan sehingga memudahkan penyerapan dari unsur mineral. Oleh karena itu, bayi yang mendapatkan IMD memiliki keuntungan yang lebih banyak dari bayi yang tidak IMD karena memperoleh unsur-unsur penting dari kolostrum dan mengurangi risiko untuk mengalami stunting. Penelitian Muchina dan Waithaka di Kenya membuktikan bahwa anak (usia 0-24 bulan) yang tidak IMD berisiko 2 kali untuk mengalami stunting dibandingkan yang mendapat IMD ${ }^{7}$. Keuntungan lainnya yang diperoleh oleh bayi yang IMD yakni memiliki peluang lebih besar untuk berhasil dalam ASI eksklusif. Hal itu dibuktikan oleh penelitian Jessica Irawan di Denpasar bahwa ibu yang melaksanakan IMD memiliki peluang 5 kali lebih berhasil untuk memberikan ASI eksklusif. ${ }^{13}$

Berdasarkan hasil penelitian dan uraian pembahasan, bayi yang tidak IMD mempengaruhi pertumbuhan tingginya di masa kelak karena tidak memperoleh manfaat dari kolostrum dan terbukti pada usia BADUTA mengalami kondisi stunting atau tinggi badan yang tidak sesuai dengan umur anak.

\section{Hubungan pemberian ASI eksklusif dengan Stunting}

Hasil penelitian menunjukkan bahwa ada hubungan pemberian ASI eksklusif dengan Stunting di wilayah kerja Puskesmas Pantoloan. Hasil penelitian ini sejalan dengan penelitian ${ }^{11}$ yang menemukkan bahwa balita yang tidak mendapatkan ASI eksklusif sebagian besar pada kelompok balita stunting $(88,2 \%)$ dibandingkan pada kelompok balita normal $(61,8 \%) .{ }^{11}$

Hasil penelitian yang diperoleh di lapangan bahwa sebagian besar BADUTA stunting 47,2\% tidak mendapatkan air susu ibu pada saat berusia 0-6 bulan. Sebagian kecil saja yakni 19\% BADUTA stunting yang mendapatkan air susu ibu pada saat berusia 0-6 bulan. Salah satu faktor yang diduga menjadi alasan tidak diberikannya ASI eksklusif dikarenakan keadaan ibu dan bayi pada usia untuk pemberian ASI eksklusif tidak memungkinkan untuk memberikan ASI eksklusif sebab sedang mengalami situasi pasca gempa dan tsunami di wilayah Kota Palu dan tidak terkecuali di wilayah kerja Puskesmas Pantoloan.

Selain itu, terdapat 55,5\% BADUTA stunting yang penolong persalinannya adalah dokter atau proses persalinannya secara operasi. Hal itu menjadi alasan lain 
bahwa BADUTA tidak mendapatkan ASI eksklusif secara utuh. Menurut hasil wawancara dengan ibu BADUTA yang melahirkan secara SC bahwa ibu bertemu anaknya setelah hari kedua atau ketiga pasca operasi dan selama selang waktu itu, bayi diberikan susu formula oleh petugas kesehatan.

Penyebab-penyebab tersebut menjadi faktor tidak langsung terhadap terganggunya keadaan status gizi anak karena mempengaruhi kondisi ibu untuk tidak memberikan ASI secara eksklusif. Padahal pemberian ASI eksklusif diketahui menyediakan semua nutrisi penting untuk pertumbuhan dan kekebalan anak dalam enam bulan pertama kehidupan hingga berusia 2 tahun sehingga menawarkan efek perlindungan. Selama pemberian ASI eksklusif, ASI sudah lebih matur dan kadar laktosa lebih tinggi dari kolostrum sehingga meningkatkan penyerapan unsur mineral. Hal itu memberi keuntungan kepada bayi karena menjadikan pertumbuhan tulang dan sistem tubuh semakin matang dan sempurna.

Penelitian yang dilakukan di pedesaan Rwanda membuktikan bahwa pemberian ASI eksklusif meningkatkan pertumbuhan linier pada anak-anak dan mengurangi risiko stunting. ${ }^{10}$ Penelitian lainnya dilakukan oleh M.Rizal Permadi di Kabupaten Boyolali menemukkan bahwa anak yang tidak mendapatkan ASI eksklusif memiliki risiko untuk mengalami kejadian stunting 7,86 kali lebih tinggi dibandingkan anak yang mendapatkan ASI eksklusif. ${ }^{14}$

Berdasarkan pembahasan diketahui bahwa faktor-faktor tidak langsung yang mempengaruhi ibu untuk tidak memberikan ASI eksklusif dapat menyebabkan peran utama nutrisi dari ASI untuk pertumbuhan menjadi tidak efektif diperoleh oleh anak. Pada akhirnya, BADUTA yang tidak ASI secara eksklusif memengaruhi atau berhubungan dengan keadaan stunting anak.

\section{SIMPULAN DAN SARAN}

Berdasarkan hasil penelitian dan pembahasan, ada hubungan IMD dan pemberian ASI eksklusif dengan stunting pada BADUTA usia 7-24 bulan di wilayah kerja Puskesmas Pantoloan. Saran peneliti bagi petugas kesehatan Puskesmas Pantoloan agar memaksimalkan dalam mempromosikan dan melaksanakan IMD dan ASI eksklusif kepada masyarakat, terutama ibu-ibu untuk mencegah dan meminimalkan kejadian stunting pada anak-anak di masa datang.

\section{UCAPAN TERIMA KASIH}

Pada kesempatan ini peneliti mengucapkan terima kasih banyak kepada 1) Nasrul, SKM. M.Kes. selaku Direktur Poltekkes Kemenkes Palu atas izin pelaksanaan penelitian ini, 2) Kepala Puskesmas Pantoloan beserta staf yang telah mendukungan dan bekerja sama dengan peneliti, dan 3).Seluruh responden yang telah bersedia ikut serta dalam penelitian ini.

\section{DAFTAR PUSTAKA}

1. Ermalena. Indikator Kesehatan SDGs di Indonesia. In: Disampaikan dalam Diskusi Panel "Pengendalian Tembakau dan Tujuan Pembangunan Indonesia." Balai Kartini; 2017. p. 12-4.

2. Afandi T. Siaran Pers Stunting Summit: Komitmen Bersama Turunkan Prevalensi Stunting di Indonesia. 2018.

3. WHO. Global Nutrition Targets 2025: Stunting Policy Brief. Geneva: WHO; 2014.

4. Kemenkes RI. Riskesdas 2013. Jakarta; 2013.

5. Kemenkes RI. Hasil Utama Riskesdas 2018. Jakarta; 2018.

6. Dinkes Provinsi Sulawesi Tengah. Masalah dan Kinerja Program Gizi di Provinsi Sulawesi Tengah. Palu; 2017. 
7. Muchina E, Waithaka P. Relationship between breastfeeding practices and nutritional status of children aged 0-24 months in Nairobi, Kenya. Afr J Food Agric Nutr Dev. 2010;10(4):2358-78.

8. Sumiaty. Pengaruh Faktor Ibu dan Pola Menyusui Terhadap Stunting Baduta 6-23 Bulan di Kota Palu Provinsi Sulawesi Tengah. J Ilm Bidan. 2017;2(2):1-8.

9. Fikawati S, Syafiq A, Karima K. Gizi Ibu dan Bayi. Jakarta: Rajawali Pers; 2016.

10. Uwiringiyimana V, Ocké MC, Amer S, Veldkamp A. Predictors of stunting with particular focus on complementary feeding practices: A cross-sectional study in the Northern Province of Rwanda. Nutrition. 2018;

11. Ni'mah K, Nadhiroh SR. Faktor yang Berhubungan dengan Kejadian Stunting Pada Balita. Media Gizi Indones. 2015;10(1):13-9.

12. Dinkes Kota Palu. Laporan Data Stunting Kota Palu Tahun 2018. Palu; 2018.

13. Irawan J. Hubungan Inisiasi Menyusu Dini (IMD) dan pemberian Air Susu lbu (ASI) Eksklusif DI RSUD Wangaya. Skala Husada. 2018;5(1):1-7.

14. Permadi MR, Hanim D, Kusnandar K, Indarto D. Risiko Inisiasi Menyusu Dini dan dan Praktek ASI Eksklusif Terhadap Kejadian Stunting Pada Anak 6-24 Bulan. Penelit Gizi Dan Makanan J Nutr Food Res. 2017;39(1). 